\section{Growth, photosynthesis and pollen performance in saline water treated olive plants under high temperature}

\author{
Georgios C. Koubouris, \\ Nikolaos Tzortzakis, \\ Nektarios N. Kourgialas, Marina Darioti, \\ loannis Metzidakis \\ Hellenic Agricultural Organization \\ "Demeter", Institute for Olive Tree and \\ Subtropical Plants, Chania, Greece
}

\begin{abstract}
Olive cultivation in hot arid areas is hindered by the scarcity of irrigation water. The exploitation of saline water has been proposed as a solution to partially cover plant water demands. This paper presents the effects of salinity [0, 60 and $120 \mathrm{mM}$ sodium chloride $(\mathrm{NaCl})]$ on physiological and reproductive functions of cultivars Koroneiki and Amphissis in a closed hydroponic system. Shoot growth was markedly reduced in high salinity dose in Amphissis (-81\%) and Koroneiki (-75\%). The photosynthetic rate was significantly reduced at $120 \mathrm{mM} \mathrm{NaCl}$ for both cultivars, as well as chlorophyll and carotenoids content (43\% and $44 \%$, respectively). The $\mathrm{Na}+$ content in all plant parts increased in both salinity doses especially in Amphissis while K concentration decreased for both cultivars. Inflorescences in Amphissis were severely damaged due to salinity. Consequently, pollen sampling and in vitro germination study was only feasible for Koroneiki. Indeed, Koroneiki pollen germination was reduced at $60 \mathrm{mM} \mathrm{NaCl}(-42 \%)$ and at $120 \mathrm{mM} \mathrm{NaCl}(-88 \%)$. Pollen tube length was also reduced by $15 \%$ and $28 \%$ for the middle and high salinity dose, respectively. The results of the present study indicate that Amphissis is more sensitive in high salinity doses compared to Koroneiki and that reproductive functions are severely affected by salinity.
\end{abstract}

\section{Introduction}

Agriculture in hot arid areas is hindered by the scarcity of irrigation water. The exploitation of saline water has been proposed as a solution to partially cover plant water demands. Most of the world's olive production is situated in the Mediterranean region and the olive is considered to be the major tree crop in this area. ${ }^{1}$ Compared to other tree crops, the olive tree is moderately tolerant to salinity. Olive cultivation often occurs in locations that are unsuitable for other crops, due to summer drought and lack of good quality water for irrigation, which leads to salinity building up in the soil. The conflicting demands for water between agriculture, civil use and tourism, all reaching higher levels, in late spring, summer, and early autumn, when water is less abundant; lead to an over-pumping of groundwater which in turn generates saltwater intrusion in several agricultural areas. Taking into consideration that olive cultivation is more and more supplemented with irrigation, salinity due to saltwater intrusion is becoming a major problem on the yield of olive crop. $^{2}$

In general, salinity is an environmental stress that limits growth and development in plants. Various effects of salinity on olive tree have been demonstrated. ${ }^{3}$ Shoot growth is affected more than root growth under a saline environment, resulting in an increased rootshoot ratio. ${ }^{4}$ There are also several genotypic variations for salt tolerance among the cultivars. ${ }^{5}$

In recent years, many studies employ hydroponic culture to study the effects of salinity on crops, ${ }^{6}$ in which the experimental process can be controlled in a more appropriate way than in field applications, excluding the plant-soil interaction interference. However, according to our best knowledge, there are limited studies dealing with olive trees in hydroponics and indeed no studies employed NFT system, which is considered suitable method for nutrition studies. ${ }^{7}$ Nevertheless, a number of unresolved issues regarding the impact of salinity on olive trees still exist.

Under Mediterranean conditions, salinity stress commonly occurs simultaneously with other environmental constrains such as high temperature and high solar irradiance. ${ }^{8}$ High temperature reduces photosynthetic and pollen performance of olive, ${ }^{9,10}$ while the impact of solar irradiance is considered as more complex due to qualitative components i.e. spectrum composition and light intensity. Aim of the present study was to investigate the effects of two $\mathrm{NaCl}$ salinity levels under enhanced temperature on physiological and reproductive functions of two olive cultivars of major importance for Greece - olive oil cv. Koroneiki and table olive cv. Amphissis.

\section{Materials and Methods}

Plants of Koroneiki and Amphissis were developed in a hydroponic system (Nutrient Film Technique-NFT) in an unheated glasshouse with a north-south orientation of the Institute of Olive Tree and Subtropical Plants of Chania. The average minimum and
Correspondence: Georgios Koubouris, Hellenic Agricultural Organization "Demeter" (formerly, NAGREF - National Agricultural Research Foundation), Institute for Olive Tree and Subtropical Plants, Agrokipion, 73100 Chania, Greece.

E-mail: koubouris@nagref-cha.gr

Key words: Olea europaea L.; photosynthesis; pollen germination; salinity.

Acknowledgements: this work was supported by General Secretariat for Research and Technology in the framework of Greek-Egyptian Bilateral Cooperation 2006-2008 (contract no. GSRT-271-e).

Contributions: GCK, experimental plan, experimental work, writing the paper; NT, experimental work, writing the paper; NNK, manuscript writing, statistical analysis; MD, experimental work; IM, experimental work supervision.

Conflict of interest: the authors declare no potential conflict of interest.

Received for publication: 26 May 2015.

Revision received: 22 June 2015.

Accepted for publication: 22 June 2015.

This work is licensed under a Creative Commons Attribution NonCommercial 3.0 License (CC BYNC 3.0).

(C) Copyright G.C. Koubouris et al., 2015

Licensee PAGEPress srl, Italy

International Journal of Plant Biology 2015; 6:6038 doi:10.4081/pb.2015.6038

average maximum temperature in the greenhouse were 18 and $38.8^{\circ} \mathrm{C}$, respectively. Each plot (three replicate plots per salinity treatment per cultivar) consisted of a separated (twin trough with a $3 \%$ slope) NFT system containing at least 10 plants. Two-year-old olive trees were fed with a complete nutrient solution. ${ }^{11}$

Plants were grown for 6 months with a basic nutrient solution. Plants were subjected to 60 $\mathrm{mM}$ and $120 \mathrm{mM}$ of $\mathrm{NaCl}$ which were added to the basic solution starting on the $2^{\text {nd }}$ week after transplanting. To avoid osmotic shock $\mathrm{NaCl}$ was applied in stepped up 4-days increments of approximately $20 \mathrm{mM}$ until the final level was reached. The nutrient solution was renewed regularly to avoid phenomena of toxicity or deficiency. The setpoints for $\mathrm{pH}$ and $\mathrm{EC}$ were 6 and $6 \mathrm{dS} \cdot \mathrm{m}^{-1}$, respectively.

During the cultivation period (6 months), the consumption of nutrient solution from the cultivars was recorded on a monthly basis. For the determination of $\mathrm{Na}$ and $\mathrm{K}$, pooled samples of roots, young shoots, old shoots, young leaves and old leaves from 3 plants were taken, dried at $65^{\circ} \mathrm{C}$ for $48 \mathrm{~h}$, and then grounded. After extraction with diluted nitric acid for $24 \mathrm{~h}, \mathrm{Na}$ 
and $\mathrm{K}$ were determined using flame photometry (PFP-7, Barloworld Scientific T/As Jenway, Gransmore Green, UK). Regarding the plant physiology parameters that were studied, new vegetation (cm/plant) and consumption of nutrient solution (Lt) were measured for comparing the tolerance of the two cultivars in the various salinity treatments.

Additionally, gas exchange measurements were made at the end of the experimental period. Ten leaves for each treatment were used to measure photosynthetic rate, stomatal conductance and intercellular $\mathrm{CO}_{2}$ concentration $(\mathrm{Ci})$ using a portable gas exchange system (LI6400, Li-Cor Biosciences, Lincoln, NE, USA).

In order to assess pollen performance of plants grown in saline culture medium, pollen was collected from freshly opened flowers and subsequently incubated at room temperature $\left(\sim 22^{\circ} \mathrm{C}\right)$ in the dark for $24 \mathrm{~h}$, in a growth chamber (Kottermann 2770, D3162; Hanigsen, Germany) before counting pollen germination and pollen tube length. Throughout the experiment, pollen was cultured on solid medium consisting of $0.8 \%(\mathrm{w} / \mathrm{v})$ agar, $15 \%(\mathrm{w} / \mathrm{v})$ sucrose, $100 \mathrm{ppm}$ boric acid and $60 \mathrm{ppm}$ tetracycline hydrochloride, according to Koubouris et al. ${ }^{10}$ Pollen germination was evaluated on five petri dish fields containing over 50 pollen grains for each treatment. Pollen tube length was measured for approximately 60 pollen tubes for each treatment.

Data were analyzed using SPSS (SPSS Inc., Chicago, USA) and were subjected to one-way analysis of variance (ANOVA). Significantly different means were calculated at $\mathrm{P} \leq 0.05$ using least significant difference (LSD) test.

\section{Results and Discussion}

Vegetative growth of both olive cultivars was significantly affected by high salinity dose (120 mM NaCl). Indeed, overall new shoot growth was reduced both for Koroneiki $(-75 \%)$ and Amphissis (-81\%) (Figure 1A). However, the results of the present study indicated that Koroneiki may grow sufficiently at mild salinity as there were no differences among $60 \mathrm{mM}$ $\mathrm{NaCl}$ and control treatments. In contrast, a major reduction of shoot growth $(-65 \%)$ even at mild salinity $(60 \mathrm{mM} \mathrm{NaCl})$ indicates higher sensitivity of Amphissis under salinity conditions. Shoot elongation was reduced by salinity (up to $80 \mathrm{meq}^{-1} \mathrm{NaCl}$ ) in Koroneiki but was unaffected in Amphissis in a previous study. ${ }^{12}$ In fact, different salinity doses were then tested and shoot elongation was measured in four selected shoots per plant, in contrast with the present study where total plant shoot growth was monitored. Shoot elongation was also affected by salinity in other olive varieties. ${ }^{2}$

Absorption of nutrient solution from the plants was studied as an indicator of plant nutrition functionality, since it is generally well established that saline conditions limit the vegetative development of olives, mainly as a result of interference with the osmotic balance in the root system zone. ${ }^{13}$ Significant reduction in the absorption of nutrient solution from the plants was recorded at high salinity dose $(120 \mathrm{mM} \mathrm{NaCl})$ both for Koroneiki (-86\%) and Amphissis (-85\%) (Figure 1B). Mild salinity dose (60 mM NaCl) had no effect for Koroneiki but suppressed nutrient absorption for Amphissis (-64\%), which is directly related with the reduced shoot elongation and/or increased sensitivity to salinity. Reduced water absorption by olive plants grown in sand-perlite (1/1) culture in a saline medium was also reported by Therios \& Misopolinos. $^{12}$

The antagonistic role of $\mathrm{Na}^{+}$and $\mathrm{K}^{+}$and the negative effect of salinity on plant nutrition were confirmed by plant tissue analysis. The $\mathrm{Na}^{+}$content increased in both salinity doses compared to the control plants (Table 1). Indeed, $\mathrm{Na}$ accumulation was higher in Amphissis compared to Koroneiki in all plant parts. It was previously shown that salinity induces detrimental effects by specific toxic accumulation of chloride and sodium ions in the leaves. ${ }^{14}$ In the present study, the $\mathrm{Na}$ accumulation was increased in salinity treatments in all plant tissues - roots, stems, shoots, leaves - in both cultivars, in agreement with Melgar et al. ${ }^{15}$ For both Koroneiki and Amphissis, it was observed that the higher the salinity dose the higher the reduction of K concentration in plant tissues (Table 1). Similar effect was reported by several studies (e.g. Chartzoulakis et al. ${ }^{16}$ ) while, in contrast, higher $\mathrm{K}$ accumulation in salt-stressed olive leaves was reported by Melgar et al. ${ }^{15}$

The leaf photosynthetic rate was signifi-
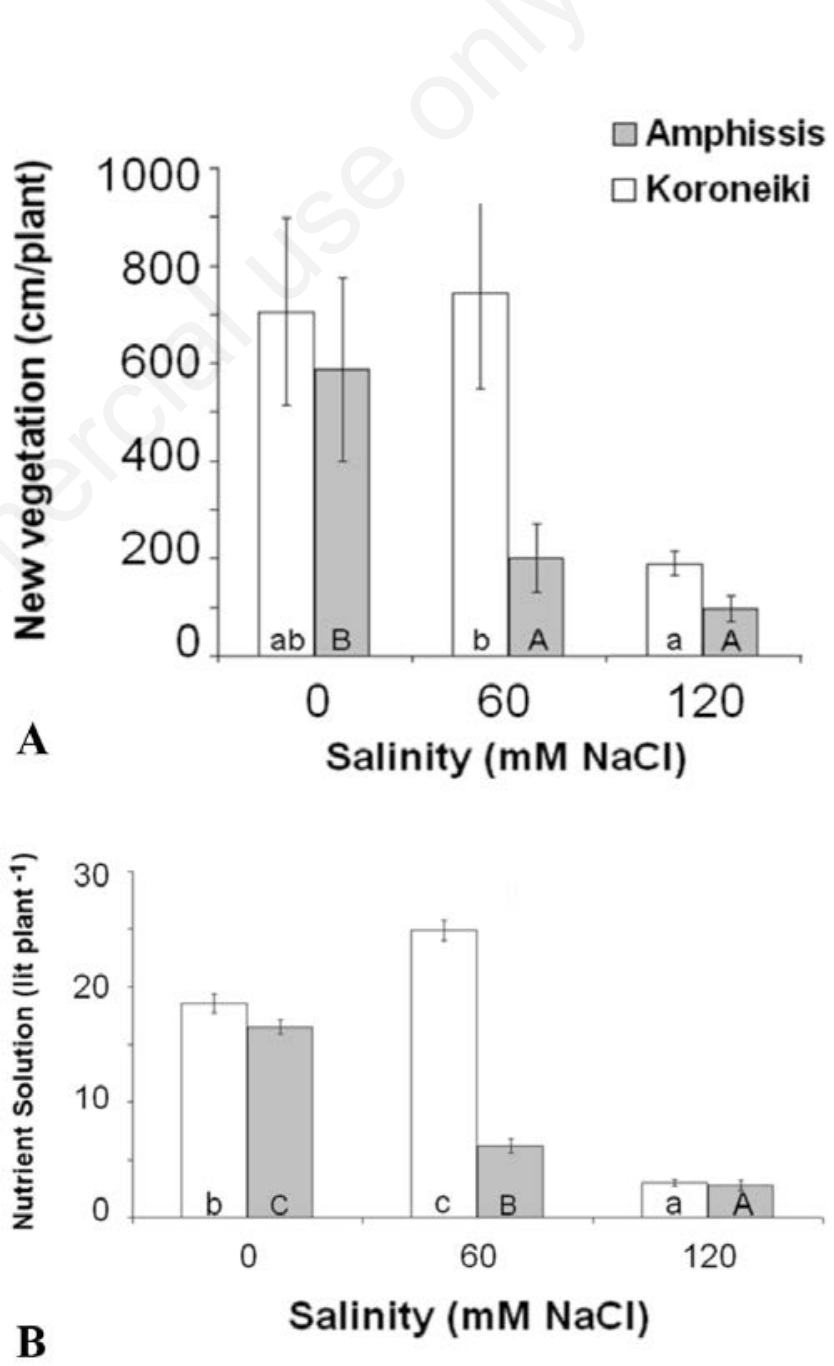

Figure 1. Influence of $\mathrm{NaCl}$ salinity $(60 \mathrm{mM}$ and $120 \mathrm{mM})$ on shoot growth of hydroponically grown olive tree Koroneiki and Amphissis in NFT (A) and on total consumption of nutrient solution of hydroponically grown olive tree Koroneiki and Amphissis in NFT (B). Each bar is mean \pm standard error for each treatment. Bars with the same letter were not significantly different at $\mathrm{P}<0.05$ [LSD test; $\mathrm{n}=10$ (A) and $\mathrm{n}=3$ (B)]. 
$\square$ Koroneiki
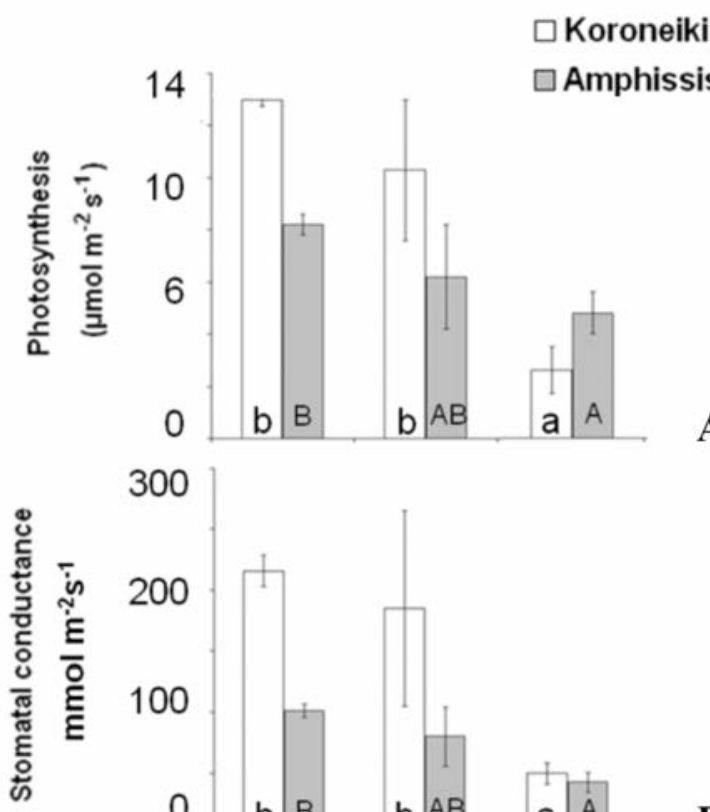

300

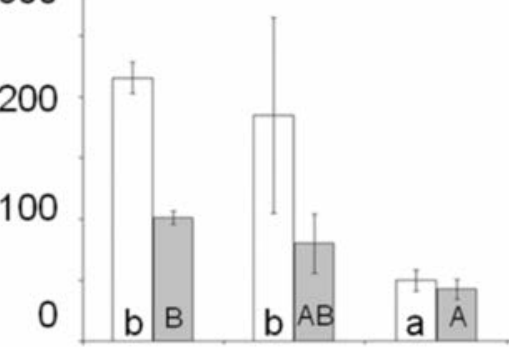

B

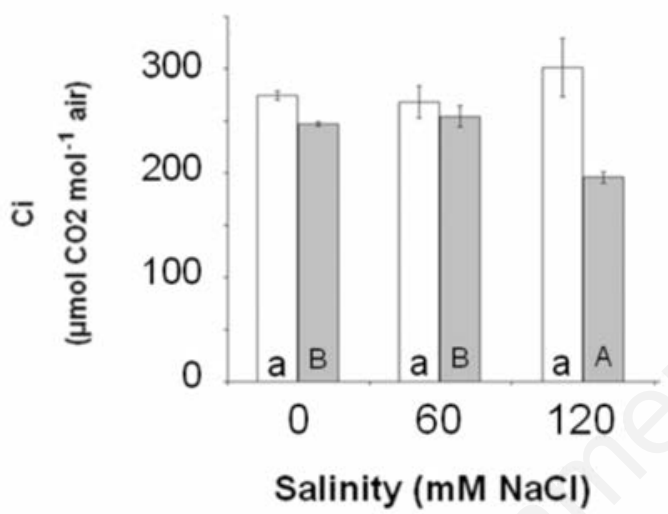

cantly reduced at $120 \mathrm{mM} \mathrm{NaCl}$ for both cultivars with greater effects observed in Koroneiki (Figure 2A). This result is in agreement with Loreto et al. ${ }^{17}$ who reported that when olive trees exposed to salt stress, cultivars with inherently high photosynthesis showed the highest photosynthetic reductions. However, sufficient carbon assimilation was retained at intermediate salinity level $(60 \mathrm{mM})$ for both cultivars compared to reference values reported for olive at normal conditions. ${ }^{18,19}$

Besides photosynthetic rate, in both cultivars, stomatal conductance was influenced by salinity in a very similar way (Figure 2B). Specifically, the reduction on stomatal conductance declined to high salinity for Koroneiki $(-78 \%)$ and for Amphissis (-60\%) which is in accordance with previous studies. ${ }^{16}$ In the present study, salinity $(120 \mathrm{mM})$ significantly reduced intercellular $\mathrm{CO}_{2}$ concentration $(C i)$ of Amphissis, however, no such effect of either salinity doses was observed for Koroneiki (Figure 2C). These results show that the reduction of photosynthesis in salt-stressed Koroneiki leaves is attributable to stomatal resistance, while for Amphissis both stomatal and mesophyll resistances are involved as it has been also reported previously for other olive cultivars. ${ }^{20}$ The simultaneous existence of biochemical limitations to photosynthesis such as carboxylation rate and efficiency is also common in salt-stressed olive leaves. ${ }^{20}$ Impairment of the photosynthetic apparatus by salinity was also indicated by a reduction in chlorophyll and carotenoids content ( $43 \%$ and $44 \%$, of the controls respectively at $120 \mathrm{mM}$ $\mathrm{NaCl}$; data not shown).

Inflorescences in Amphissis were severely damaged due to salinity. Consequently, pollen sampling and in vitro germination study was only feasible for Koroneiki. This also highlights the increased sensitivity to salinity damage of Amphissis compared with Koroneiki as

Figure 2. Influence of $\mathrm{NaCl}$ salinity $(60 \mathrm{mM}$ and $120 \mathrm{mM})$ on (A) photosynthesis rate, (B) stomatal conductance, and (C) substomatal $\mathrm{CO}_{2}$ concentration $(\mathrm{Ci})$ of hydroponically grown olive tree Koroneiki and Amphissis in NFT. Each bar is the mean \pm standard error for each treatment. Bars with the same letter were not significantly different at $\mathbf{P}<0.05$ (LSD test, $\mathbf{n = 1 0}$ ).

Table 1. Influence of $\mathrm{NaCl}$ salinity $(60 \mathrm{mM}$ and $120 \mathrm{mM})$ on $\mathrm{K}$ and $\mathrm{Na}$ content in different plant tissues of hydroponically grown olive tree Koroneiki and Amphissis in NFT. A composite sample from 4 plants was analyzed for each case.

\begin{tabular}{|c|c|c|c|c|c|c|c|}
\hline Salinity (mM NaCl) & Variety & Element & Root & Young leaves & $\begin{array}{c}\% d w \\
\text { Old leaves }\end{array}$ & Young shoots & Old shoots \\
\hline 0 & Koroneiki & $\mathrm{K}$ & 1.58 & 2.05 & 2.00 & 1.68 & 0.96 \\
\hline 60 & Koroneiki & K & 0.67 & 1.73 & 1.38 & 1.25 & 0.99 \\
\hline 120 & Koroneiki & $\mathrm{K}$ & 0.70 & 1.20 & 1.03 & 0.92 & 0.81 \\
\hline 0 & Amphissis & K & 0.31 & 2.53 & 2.17 & 2.72 & 1.78 \\
\hline 60 & Amphissis & K & 0.49 & 2.29 & 1.73 & 2.47 & 1.43 \\
\hline 120 & Amphissis & K & 0.35 & 1.78 & 1.20 & 1.20 & 0.57 \\
\hline 0 & Koroneiki & $\mathrm{Na}$ & 0.27 & 0.24 & 0.25 & 0.31 & 0.20 \\
\hline 60 & Koroneiki & $\mathrm{Na}$ & 0.27 & 0.44 & 0.57 & 0.39 & 0.36 \\
\hline 120 & Koroneiki & $\mathrm{Na}$ & 1.70 & 1.33 & 1.87 & 1.56 & 1.05 \\
\hline 0 & Amphissis & $\mathrm{Na}$ & 0.08 & 0.19 & 0.16 & 0.25 & 0.21 \\
\hline 60 & Amphissis & $\mathrm{Na}$ & 0.71 & 1.19 & 1.16 & 1.76 & 1.09 \\
\hline 120 & Amphissis & $\mathrm{Na}$ & 1.01 & 1.96 & 2.34 & 2.28 & 0.78 \\
\hline
\end{tabular}


the reproductive phase of the tree, being more sensitive and susceptible to stresses, was more damaged compared to the vegetative part of the tree (i.e. stems and leaves). Indeed, Koroneiki pollen germination was reduced at $60 \mathrm{mM} \mathrm{NaCl}(-42 \%)$ and at $120 \mathrm{mM} \mathrm{NaCl}$ $(-88 \%)$ as presented in Figure 3A. Pollen tube length was also reduced by $15 \%$ and $28 \%$ for the mild and high salinity dose, respectively (Figure 3B).

Data on olive pollen germination in response to salinity are scarce. In olive, pollen performance is reduced at high temperature, ${ }^{10}$ similarly with photosynthetic activity. ${ }^{9}$ A number of previous studies are in agreement with the present results highlighting the increased importance and scientific interests on salinity effects on crops. In a previous study on 5 Pistacia species, pollen was found to be more sensitive to salinity compared to seeds. ${ }^{21}$ Exposure of 3 Cicer arietinum L. varieties to salinity induced reduction of pollen production, germination and tube length, especially at higher doses. ${ }^{22}$ Similarly, reduced pollen viability and germination was observed for Brassica napus L. plants previously irrigated with sea water solutions. ${ }^{23}$ In a relevant study on $B$. napus L., pollen germination was shown to better reflect overall plant sensitivity to salt stress compared to pollen tube length, ${ }^{24}$ which also reflects and supports the present findings as the pollen germination provided clearer evidence on salinity effects compared to data pertaining to pollen tube length.

In order to overcome the water deficit due to increased water needs in agriculture, many countries may have to use water of lower quality such as saline water or treated waste water. study of the effects of salinity on plants must be performed. This study elucidates the response to salinity stress of two major olive cultivars in Greece, Koroneiki and Amphissis, through several physiological and reproductive indicators. Specifically, the findings of this work indicate that Amphissis physiological processes are more sensitive in high salinity doses compared to Koroneiki. However, olive tree response to salinity may vary as influing methodology ${ }^{25}$ soil type and precipitation intensity and distribution in the area of cultivation. The results of the present study also indicate that reproductive functions are severely affected by salinity. Therefore, future salinity studies would benefit from addition of In order to achieve that, however a detailed enced by agronomic practices $e$. .g proper leach-

reproductive indicators to investigate whether a plant can not only grow but also produce sufficiently under saline conditions.

\section{References}

1. Paranychianakis NV, Chartzoulakis KS. Irrigation of Mediterranean crops with saline water: From physiology to management practices. Agricult Ecosyst Environ 2005;106:171-87.

2. Perica S, Goreta S, Selak GV. Growth, biomass allocation, and leaf ion concentration of seven olive (Olea europaea L.) cultivar under increased salinity. Sci Hort 2008;117:123-9.

3. Tattini M, Traversi ML. On the mechanism of salt tolerance in olive (Olea europaea L) under low or high- $\mathrm{Ca}^{2+}$ supply.Environ Exper Bot 2008;65:72-81.

4. Chartzoulakis K, Loupassaki M, Bertaki M, Androulakis I. Effects of $\mathrm{NaCl}$ salinity on growth, ion content and $\mathrm{CO}_{2}$ assimilation rate of six olive cultivars. Sci Hort 2002;96:235-47.

5. Benlloch M, Ojeda MA, Ramos J, Rodriguez-Navarro A. Salt sensitivity and low discrimination between potassium and sodium in bean plants. Plant Soil 1994;166:117-23.

6. Chondraki S, Tzerakis C, Tzortzakis N. Influence of $\mathrm{NaCl}$ and calcium foliar spray on hydroponically grown parsley in NFT system. J Plant Nutr 2012;35:1457-67.

7. Tzortzakis NG. nfluence of $\mathrm{NaCl}$ and calcium nitrate on lettuce and endive growth using nutrient film technique. Int J Veget Sci 2009;15:1-13.

8. Chaves MM, Maroco JP, Pereira JS. Understanding plant responses to drought-from genes to the whole plant. Funct Plant Biol 2003;30:239-64.

9. Koubouris GC, Kavroulakis N, Metzidakis IT, et al. Ultraviolet-B radiation or heat cause changes in photosynthesis, antioxidant enzyme activities and pollen performance in olive tree. Photosynthetica 2015;53:279-87.

10. Koubouris GC, Metzidakis IT, Vasilakakis MD. Impact of temperature on olive (Olea europaea L.) pollen performance in relation to relative humidity and genotype. Environ Exper Bot 2009;67:209-14.

11. Economakis CD, Daskalaki AA, Metzidakis IT. Seasonal variation in water and nutrient uptake by olive plants grown in solution culture. Proceedings of the International Symposium on the Olive Tree and the Environment 2003;85.

Figure 3. Effect of $\mathrm{NaCl}$ salinity $(60 \mathrm{mM}$ and $120 \mathrm{mM})$ on (A) pollen germination $(n=250)$ and (B) length of pollen tubes $(n=60)$ for hydroponically grown olive tree Koroneiki in NFT. Amphissis pollen was unavailable due to salinity-induced damaged inflorescences. Each bar is the mean \pm standard error for each treatment. Bars with the same letter were not significantly different at $\mathbf{P}<\mathbf{0 . 0 5}$ (LSD test).
12. Therios I.N, Misopolinos ND. Genotypic response to sodium chloride salinity of four major olive cultivars (Olea europaea 
L.). Plant Soil 1988;106:105-11.

13. Tattini M. Ionic relations of aeroponicallygrown olive genotypes during salt stress. Plant Soil 1994;161:251-6.

14. Hassan MM, Seif SA, Morsi ME. Salt tolerance of olive trees. Egypt $\mathrm{J}$ Horticult 2000;27:105-16.

15. Melgar JC, Syvertsen JP, Martinez V, Garcia-Sanchez F. Leaf gas exchange, water relations, nutrient content and growth in citrus and olive seedlings under salinity. Biol Plant 2008;52:385-90.

16. Chartzoulakis K, Psarras G, Vemmos S, et al. Response of two olive cultivars to salt stress and potassium supplement. J Plant Nutr 2006;29:2063-78.

17. Loreto F, Centrito M, Chartzoulakis K. Photosynthetic limitations in olive cultivars with different sensitivity to salt stress. Plant Cell Environ 2003;26:595-601.

18. Sofo A, Dichio B, Xiloyannis C, Masia A. Lipoxygenase activity and proline accumulation in leaves and roots of olive trees in response to drought stress. Physiol Plant 2004;121:58-65.

19. Sofo A, Dichio B, Xiloyannis C, Masia A. Antioxidant defences in olive trees during drought stress: changes in activity of some antioxidant enzymes. Funct Plant Biol 2005;32:45-53.

20. Centrito M, Loreto F, Chartzoulakis K. The use of low $\left[\mathrm{CO}_{2}\right]$ to estimate diffusional and non-diffusional limitations of photosynthetic capacity of salt-stressed olive saplings. Plant Cell Environ 2003;26:58594.

21. Martinez-Palle E, Herrero M, Aragues R, et al. Salt response of seeds and pollen of five
Pistacia species. Acta Hort 1995;419:49-54.

22. Dhingra HR, Varghese TM. Flowering and male reproductive functions of chickpea (Cicer arietinum L.) genotypes as affected by salinity. Biol Plant 1993;35:447-52.

23. Gul H, Ahmad R. Effect of salinity on pollen viability of different canola (Brassica napus L.) cultivars as reflected by the formation of fruits and seeds. Pak $\mathrm{J}$ Bot 2006;38:237-47.

24. Tyagi RK, Rangaswamy NS. Screening of pollen grains vis-à-vis whole plants of oilseeds brassicas for tolerance to salt. Theor Appl Genet 1993;87:343-6.

25. Wiesman Z, Itzhak D, Ben Dom N. Optimization of saline water level for sustainable Barnea olive and oil production in desert conditions. Sci Hort 2004;100:25766 . 